\title{
Key Economic and Social Challenges for Latin America: Perspectives from Recent Studies
}

\author{
DAVID DE FERRANTI* ${ }^{*}$ AND ANTHONY J. ODY ${ }^{* * *}$
}

The paper draws on recent studies at the World Bank and elsewhere to highlight four aspects of Latin America's current challenges. First, high inequality, partly related to historical relations between Europeans, indigenous and Afro-descendants, but reinforced by continuing dualism between the formal and informal sectors. Second, education, where the region suffers from a serious "secondary deficit" and weak educational quality. 'Third, the business climate, which cxhibits continuing problems with inappropriate regulation while infrastructure provision has suffered from cutbacks co public provision, only parrly compensated for by increased private investment. Finally, Latin America's future sources of international comparative advantage: whether in natural resource-based exports or in manufacturing, the region necds to improve performance in mobilizing knowleclge and technology.

Keynuonds: Latin America, economic and social development, growth, inequality, education and technology, investment and competitiveness

* The authors gratciully acknowledge the assistance of Todk: Pugatch with graphics for this paper.

* First author. David de Ferranti, Senior Fellow, UV Foundation, 1225 Connecticle Avenue, NW, Fouth Floor: Washiugter. D.C. 20036, UISA: E-molil: Davidudefertartiotg

**s Direct all correspondence to Anthony J. Ody, UN Foundation, 1225 Connecticut Avenue, NW. Fourth Floor, Washington, D.C. 20036, USA; I'd: 1-202-778-3517; E-mai: Aody(a. unfourdation.org 


\section{INTRODL'CTION}

$\mathrm{O}$

ver roughly the past decade and a half, most Latin American countries have made important changes to the cconomic model they had followed since the 1940s, an inherited model sometimes categorized in simplificd terms as "state-directed inward-looking development" (or "state-led import-substituting industriatization (ISI)"). The initiative to make lundanental changes reflected a broad sense among many analysts and policymakers that the carlier model was not serving their colntries well. Among clements prompting fundamental rethinking were the crisis conditions experienced in many Latin American rountries during the 1980s - including external debt crisis, hyperinflation, and macroeconomic stagnation or decline. Beyond this, it had becone cluar that comparator countries in some other regions in the world, including most obviously East Asia, had ridden out some of the same external shocks as Latin America including the oil price and interest rate shorks of the 1970s and 1980s) with less trauma and, more broadly, had achicved supcrior growth and development performance over an extended period.

The changes implemented have included substantial measures of (largely unilateral) libcralization of foreign trade and of inward forcign direct investment (FD), and the privacization of many statc-owned industries, utilities, and banks. In addition, despite variations across countries and time periods, most councries have generally adieved inproved fiscal and monetary management, implemented efforts to upgrade regulation and supervision within newly-liberalized funascial sectors, and, albeit in some cases only after traumatic crises, attained increased exchange rate flexibility.

Taken rogether, these changes have becn associated with improvements in various indicators of economic and social performance. Inflation, running at hyperinflation levels in many countries during the 1970s and 1980s, has now in most cases been reduced to single digit levels. The region has also begun to make up some of the ground lost earlier in relative shares of world trade. At a more localiecd level, service coverage by some of the privatized utilitics (which often became leacling recipients of inward FDI) has expanded to harger shares of domestic populations. Wich this said, the overall results of the reforms have in most countries disappointed the more ambitious hopes inirially held for them. Growth in per capita GDP, although generally improved from the stagnation (or worse) of the $1980 \mathrm{~s}$, has still in most cases been comparatively modest and well below "miracle" rates, with only Chile matching East Asian successes on a sustained basis. A simple comparison, for example, shows average growtl in per capitat GDP in the region improvitug from 0.7\% during 1973-90 to $1.4 \%$ during the 1990 s (OECD 2001).

More sophisticated comparisons, which have sought to disaggregate the impact of exogenous conditions from those of domestic policies, have generated higher estimates for the positive impact of policy changes. A careful stiudy conducted at the World Bank, for exanple. concluded that "for most reforming countries 
[in Iatin America in the 199(s)\} the growth contriburion from structural and stabilizatiun reforms amounted to 2.5-3.0 percentage points [per annuml" (Loayza et al. 2002, 2003). Nonetheless, it bears repeating that such estimates of improiements start out from a very low base.

Meanwhile, progress in bringing down the region's disturbingly high levels of poverty (and extreme poverty) has proved slow at best (Figure 1) and subject to reversals when the overall macro picture has turned cloudy. More encouragingly, most countries have managed to arhieve sustained improvements in human development indicators, even during periuds of mediocre macroeconomic performance.

Figleke 1. Ponekty as a Share of 'jotal poplation

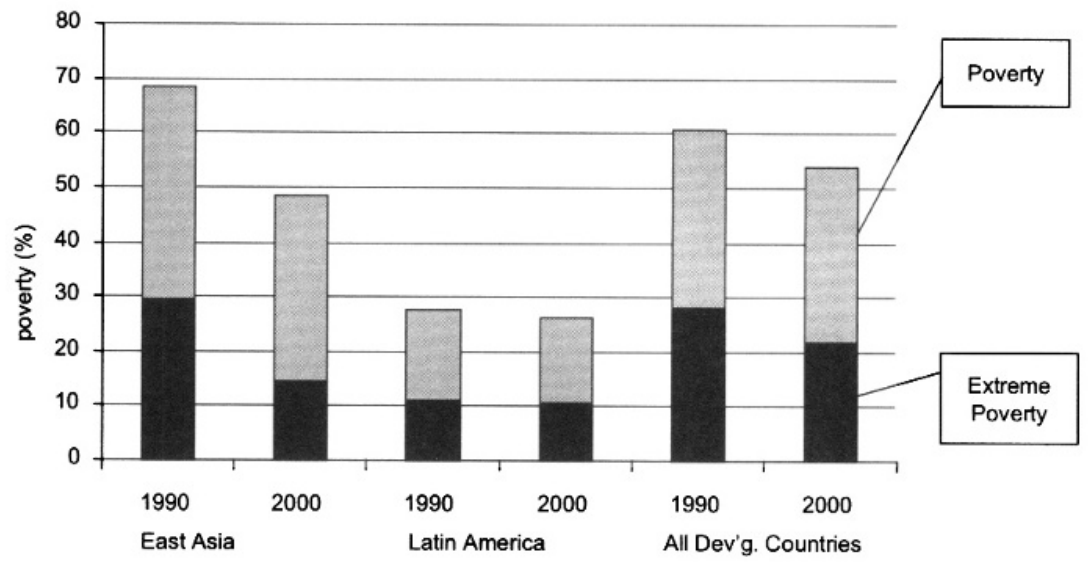

SOURC.E: Ches: and Ravallion (2001)

In the above context of moderate gains but continuing unfulfilled hopes, the present paper will highlight selectively central aspects of some of the nust important thatlenges that face the region. In doing so, the paper will draw to a significant degree on the findings of research studics conducted over recent years at the World Bank, primarily under the overall direction of onc of the present authors (de Ferranti). in his capacity as Regional Vice President for Latin America and the Caribbean (2000-05). The paper highlights four areas: 1) inequalicy: 2) education and technology; 3) the investment climate (including the provision of infrastructure); and 4) Latin American countries' intcrnational conpetitiveness and compararive advanage. This list does not exhaust the major issues that will critically determine the region's future progress. A more comprehensive (rentment would have more to say, for exampke, about such issues as: 1) the detcrminants of aygregrate savings and investneme in the region; and 2) the challenge of institurional reform and improved governance within the public sector. Having said this, the four areas of focus in the present article all meet the twin conditions that they are of the highest intrinsic importance and that the recent research to be cited in this article has significanty improved 
our understanding of the nature of the challenges involved.

\section{INEQLIALITY}

Unusually high levels of inequality by international standards represent a pervasive feature of most Latirn American societics. ' On avcragc, the richest $1.0 \%$ of individuals received about $48 \%$ of total income in Latin America in the carly 1990s; while the poorest $10 \%$ received just $1.6 \%$ of the total (comparable ratios for Asia would be $37.4 \%$ and $2.6 \%$ respectively, and for OECD nations, $29.1 \%$ and $2.5 \%$ ). As seen in Figure 2 below, whose bars each show the gini cocfficient measuring the concentration of income at the level of an individual country, the most egalitarian countries in Latin America show a degree of concentration comparalle to the least cgalitarian countries elsewhere in the world.

FigL:RE 2. Distribl:tion OF HOISEHOLI PER CAPITA INCOME, 19\%0S

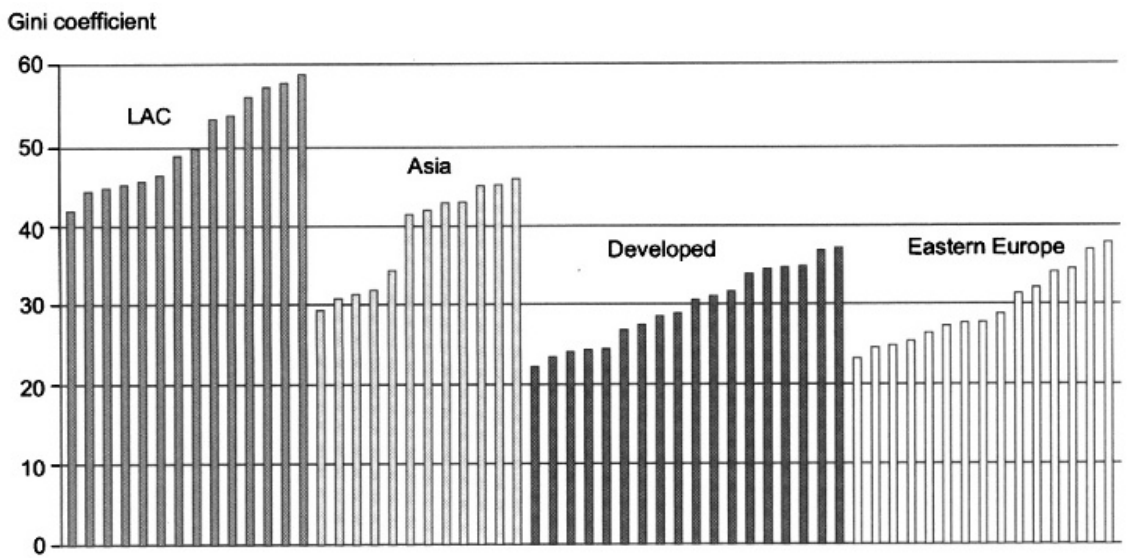

SOURCE: de Ferranti or al. (2004)

Inequality pervades not only with respect to the distribution of income (and assets), but also different individuals' access to public services, including education, health, watcr and other utilities, and their interactions with organs of the state (including in the sphere of law and order). The difference in average ycars of education between adults in the top and bottonn incone quintiles, for example, ranges from five to nine years in different countrics in the region (sec also section on Edwation, below). Inecuality also appears pervasive over time. Available data, which cxtcnd back to 1950, suggest that Iatin American countries have consistently been among the most unequal internationally throughout the perind. Among the more striking features of inequality in Latin America, in fact, has been its apparently limited variance to changes in policy regime and economic environment. 
Indeed, the origins of current stratification in Iatin American sucieties must in large part be sought in long-term historical patterns. The sixteenth century European conquest of the region's pre-Colombian indigenous socictics, supplemented by the introduction in selected parts of the region of African slaves, involved the creation of a range of mutually-reinforcing institutions, in labor management; land use, and political control, which consolidated the colonists' influence and wealth. In general, the subsequent achievement of independence from Europe in the early nineteenth century, and the later aholition of slavery, did relatively little to disrupt the effective control by small domestic elites and the high degrec of social stratification. Even today, in countries with significant indigenous and/or Afro-descendant populations, such as Bolivia, Brazil, or Guatemala, average incomes among these groups are typically half those of their "white" counterparts. ${ }^{2}$ These unequal outcomes in turn reflect a range of underlying inequalities in access to education, public scrvices and credit, as well as unequal land distribution. They also appear in some setrings ro reflect continuing discrimination in job markets.

Running alongside these racial and ethnic divides, and often overlapping with them, is the dualism that characterizes many Iatir American societies, and the stark contrasts between the "formal" and "informal" sectors of the economy. As argued in de Soto's (1989) influential study of informality in Peru, enterprises and workers functioning outside the formal sector tend to find themselves in a legal "no man's land" in which rules and property rights are ill-defince, access to formal markets such as that for credit largely foreclosed, and rclations with public sector institutions often characterized by predatory hehavior (see also section on (limate for Business, below).

Beyond these widely-discussed economic aspects of dualism, though, is a division between formal and informal workers in access to public programs of social protection. The former typically have access to a range of programs such as pensions, healthcare, and unemployment insurance, while the latter fall largely uutside what has been described as a "rouncated welfare state" (ele Ferranti, 2004, 14). This limited coverage of the population by public programs is itself not unrelated to the relatively low share of fiscal revenues in GDP in most Latin American countries. The weakness of social safety nets, in turn, can be idencified as contributing to the observed tendency for macroeconomic andior financial crises to have a particularly damaging effect in the region in setting back progress in the reduction of poverty.

Why should policy analysts be concerned about Latin America's unusually high levels of inequalicy? First, higher levels of incquality mean that, for any given level of average income, absolute levels of poverty and matcrial deprivation will be higher, as will the effort needed to reduce poverty. Second, a growing literacure suggests, on the hasis of empirical work, that extreme levels of ineciuality per se represent an obstacle to higher rates of economic growth. In a highly unequal society, many intrinsically talented individuals are likely to be denied access to secondary and tertiary levels of education, and to other opportunities such as credit. 
Inecuuality has also been corrclated with higher levels of crime and violence (serious problcms for Iarin America). Finally, a system that is perceived by its own population to produce extreme inequality of opportunity (which survey data indicate is the case in Latin America) risks weakened political legitimacy, and may have difficulty taking necessary policy decisions with any degree of consensus.

Given the region's present high inequality, what are the prospects for significant change? As far as current trends are concerned, both positive and negative elements can be identified. On the pusitive side, recent improvements in overall economic management have probably on balance been pro-poor, given the costs that hyperinflation and macro-financial crises alike impose on the most vulnerable groups. More profoundly, one can point to the positive implications of the region's political transformation over the past gencration from domination by unelected authoritarian (frequently military) governments to the near-total reliance on elections - more or less frec and more or less compctitive - as the means for changing administrations. Dcmocratization at the national level, cogether with the widespread increase in the role of elected local govemments (Burki et al. 1999), has opened up increasing space for those ourside traditional elites, including representatives of traditionally neglected groups like the indigenous and Afro-descendants, to have their voices heard and their concerns addressed. Thus, in Brazil, the Lula administration (which took office in 2003) has encouraged unprecedented public discussion of educational under-performance by Afro-Brazilians and possible policy responses. Meanwhile, the political role played by organizations aspiring to represent indigcnous groups has increased substancially in several Andean countries over recent years, though it must be added that these changes have been playing out amid considerable political turbulence.

More concretely, there is evidence of at least some public programs teaching the hitherto excluded. As the reach of services like primary education and basic infrastructure has expanded increasingly closer to universal coverage, there is evidence that the distributional impact of marginal public expenditures bas beco significantly more progressive than that of anerage public spending. A fortheoming study of the region's indigenous population by two World Bank authors finds that while gaps persist between indigenous and non-indigenous in many areas (including poverty, employment, health, and education), the gap in the average number of years of education completed, in particular, has narrowed very substantially over recent decades (Hall and Patrinos forthcoming). This said, there is evidence to suggest that the average quality of education received by indigenous children may still be below that received by non indigenous students. In a potentially encouraging finding, whouth, the same authors report that the number of councrics offering bilingual education to indigenous children in the early grades, which has been found to improve school performance, has increased from six in the early $1970 \mathrm{~s}$ to eighteen currently. On a separate note, studies of relatively recently-introduced targeted anti-poverty initiatives, specifically "conditional cash transfer" programs, 3 
suggest that they can prove highly effective at reaching the poorest groups in the population, including the indigenous (de Ferranti et al. 2004, 277).

Despite these indicators of partial progress, it remains the case that, as indicated earlier, the overall pace of change in this area appears slow at best. One trend that may, at least temporarily, work in the direction of increasing inequality, has been the apparent increase in demand (and remuneration) for relatively more highly skilled workers. Some observers have rolated this increased demand for skills in part to the opening of Latin American economies to incteased competition from more technically advanced producers in other regions. If combined with an initially inelastic supply of more skilled workers, the first-round impact of such a shift would indeed be predicted to increase income gaps. There is evidence from Chilc and Mexico, however, which have a longer experience of liberalization. that such increases in wage differentials may subsequently reverse themselves (de lerranti ct al. 2002, 12).

Fven on the most optimistic of interpretations, however, it would be difficult to rest a great deal of confidence purely on the continuation of current trends to produce a rapid reduction in the current extreme levels of inequality in the region. To the contrary, given the deep-seated nature of the mutually-reinforcing elemenes that have inceracted to produce inequality up to now, detcrmined and broad-ranging efforts appear called for to underpin decisive progress rowards greater equity. One key will be to improve access to education and, in parallel, to make improvements in its quality (sece also following section on Education). In parallel, there is considerable scope, given adequate policical (and fiscal) will, to improve the level of public services more generally, and the coverage of basic social safety net programs, including building pragmatically on proven success stories like the conditional cash transfer programs. Beyond this, policies are needed to help make markets and infrastructure work better for ordinary people and the poor (see also the later section on the Climatc for Business). Finally, special efforts may be required to help address the particular noeds of historically marginalized groups, including the indigenous and $\mathrm{Afrodesicndants.}$

\section{EDUCATION AND INNOVA'IION}

Whether focusing primarily on equity, as above. or on economic dymamism and competitiveness, attention is drawn to the stace of education across Latin America. It is an arca in which over rhe jast forty-five yeats or so, in spire of important improvements in coverage, Iatin America has generally failed to keep pace with the enormous leaps forward in some of the more dynamic comparator countrics around the world. In parallel, comparative studies of technolorical progress also find Latin American countries gencrally underperforming comparators on a range of indicators of innovation. 


\section{Education}

We start with education. There has been some progress at the quantitative level. Over the past two decades, for example, the average years of schooling of Latin Annerica's adult population (twenty-five and older), i.e., the stock of educational skills in the population at large, increased by 1.7 years (from 4.1 to 5.8 years). At the level of flow's, in other words the educational level of children actually passing through the school age years during the period, most Latin American countries came close to universal coverage of at lease some primary school actendance for all children. Earlier gender gaps in school attendance were also narrowed or eliminated over the period.

Despite these gains, however, Latin American countries have tended to fall behind the progress in comparable countries elsewhere. When mean years of schooling in the adult population are regressed against per capita GDP for 105 countrics workdwide, for cxample, Iatin American countries on average show a defait of 1.4 years of schooling per person, compared to what would he predicted based on their level of per capita GDP. The East Asian tigers, by contrast, on average show 1.0 years more education than would he predicted, while the natural resource-abundant comparator countries show an average of 1.4 years more. As Figure 3 illustrates, the present situation reflects the reversal of an earlier education deficit in East Asia in 1960, while the deficit compared to GDP in Latin America increajed slightly over the same period.

\section{Figtikf 3. Deficits and Stirplises in Mean Years ol SchoOling (Compared to Levels Predicted hy pek CApita GDP)}

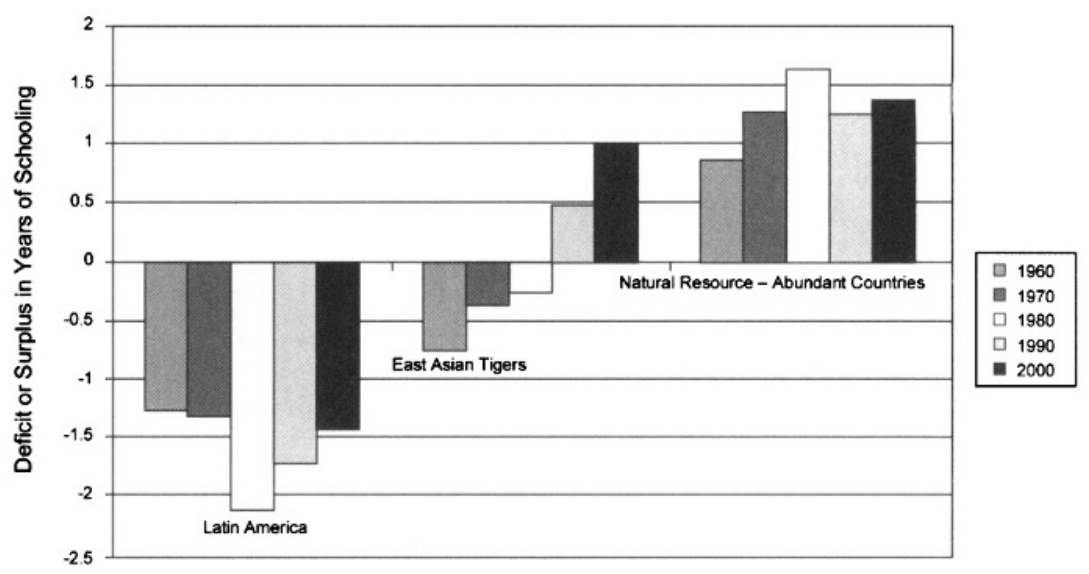

SOLRCE: de Feranci er al. (2003)

Comparative studies further indicate that the distribution of educacion wirhin much of Latin America is typically less equitable than within the comparator groups. 
Table 1 shows the proportion of adults with, respectively, 1) no education; 2) at least some primary school; 3) some secondary school; and 4) some tertiary education, for Latin America and the two comparator groups.

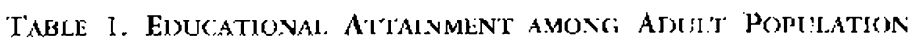

\begin{tabular}{|c|c|c|c|c|c|}
\hline & \multicolumn{5}{|c|}{ Fraction of the Adult Population } \\
\hline & $\begin{array}{l}\text { Years of } \\
\text { Schooling }\end{array}$ & No Schoul & $\begin{array}{c}\text { Some } \\
\text { Primary }\end{array}$ & $\begin{array}{c}\text { Some } \\
\text { Secondary }\end{array}$ & $\begin{array}{c}\text { Some } \\
\text { Tertiary }\end{array}$ \\
\hline Latine Amcrica & 5.8 & 17.9 & 50.1 & 20.3 & 11.8 \\
\hline Argentina & 8.5 & 5.8 & 496 & 24.9 & 19.7 \\
\hline Bolivia & 5.5 & 1.4 & 39.8 & 469 & 11.9 \\
\hline Brizil & 4.6 & 21.3 & 56.8 & 13.5 & 8.4 \\
\hline Chilc & 7.9 & 5.3 & 12.9 & 36.0 & 15.8 \\
\hline Colombia & 5.0 & 19.8 & 18.9 & 21.4 & 9.9 \\
\hline Conta Rica & 6.0 & 9. 4 & 60.7 & $! 1.3$ & 18.6 \\
\hline Cuba & 7.8 & 5.8 & 10.3 & 42.6 & 11.3 \\
\hline Dominican Republic & 5.2 & 25.6 & 46.8 & 13.1 & !) 1.5 \\
\hline Fcuador & 6.5 & 17.8 & 45.2 & 18.3 & 18.7 \\
\hline E) Salvador & 4.5 & 35.0 & 45.6 & 8.8 & 10.6 \\
\hline Guatemala & 3.1 & 47.1 & 37.6 & 9.5 & 5.8 \\
\hline Maiti & 2.7 & 54.4 & 32.3 & 12.3 & 1.0 \\
\hline Honduras & 1.1 & 25.9 & 57.0 & 10.6 & 6.5 \\
\hline Janmaicà & 5.2 & 3.4 & 54.5 & 38.0 & 4.1 \\
\hline Mexico & 6.7 & 12.4 & 47.3 & 29.0 & 11.3 \\
\hline Nicaragua & 1.1 & 31.6 & 43.0 & 16.5 & 8.9 \\
\hline Panama & 7.9 & 11.3 & $40 . \dot{4}$ & 28.5 & 19.8 \\
\hline Paraguay & 5.7 & 9.8 & 63.8 & 18.1 & 8.3 \\
\hline Peru & 7.3 & 13.8 & 35.7 & 28.1 & 27.4 \\
\hline Trinidad and Tobago & 7.6 & 5.1 & 46.3 & 44.1 & 4.5 \\
\hline Uruguay & 7.3 & 3.2 & $\$ 2.2$ & 32.1 & 12.5 \\
\hline Veraczucla & 5.6 & 15.7 & 56.6 & 9.7 & 18.0 \\
\hline East Asian tigers & 9.7 & 10.2 & 23.5 & 47.4 & 18.9 \\
\hline Hong Kong (china) & 9.5 & 10.7 & 26.6 & 47.4 & 15.3 \\
\hline Korea & 10.5 & 8.0 & 16.7 & 49.5 & 25.8 \\
\hline Malaysia & 7.9 & 13.9 & 35.6 & 43.0 & 7.5 \\
\hline Singapore & 8.1 & 12.6 & 28.3 & 48.5 & 10.6 \\
\hline Natural resource-abundant countries & 11.1 & 1.7 & 21.1 & 38.6 & 38.7 \\
\hline Australia & 10.6 & 2.2 & 24.4 & 43.6 & 29.8 \\
\hline Canata & 11.4 & 1.7 & 18.6 & 26.6 & 53.0 \\
\hline Finland & 10.1 & 0.4 & $29 . ?$ & 47.3 & 23.2 \\
\hline New Zealand & 11.5 & 0.0 & 32.2 & 26.3 & 41.6 \\
\hline Norway & 11.9 & 1.2 & 11.5 & 62.5 & 24.8 \\
\hline Sweden & 11.4 & 2.0 & 17.7 & 57.2 & 23.1 \\
\hline
\end{tabular}

NOTE: Regional averages are woighted by the population aged 25 os oldes is a country. SOURCE: de Ferranti et al (2003) 
Overall, Latin American countries tend to have larger proportions of their adult populations with either no formal education at all or only primary schooling. More unexpected, perhaps, is a broader tendency for councries in Latin America to exhibit educational distributions that appear "unbalanced" in terms of the relationship between the different levels of education, including the relationship between the secondary and tertiary levels. Compared to incemational norms, much of Latin Anerica can be said to suffer from a mussive "sccondary deficit" - with abnomally low proporcions of the population achieving some secondary education without going on to the university level. This secondary deficit, relative to what would be predicted by levels of per capita GDP, is estimated at an averagt $18.7 \%$ of the population for Latin America as a whole. Figure 4 below illustrates secondary deficits (or surpluses) for individual countries.

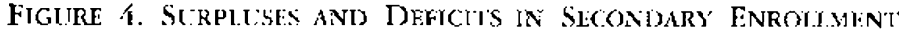 (Compared to levels Preijictfo by pfr Capita GDP)}

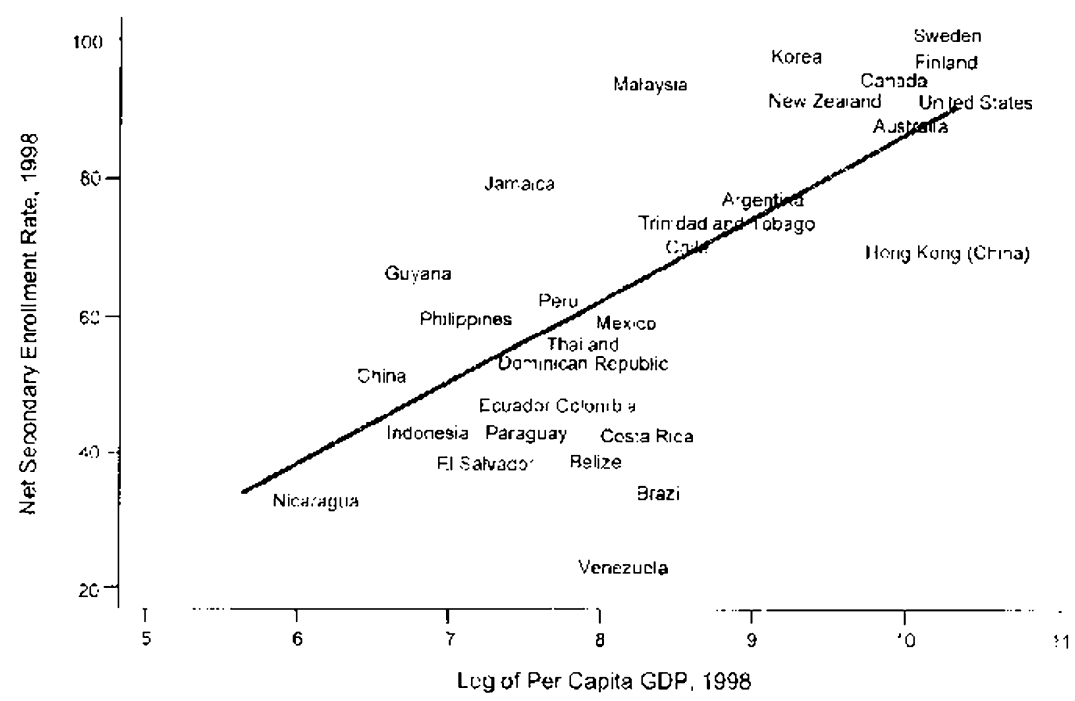

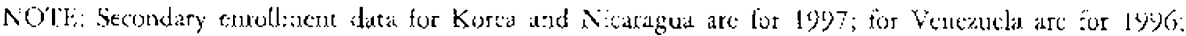
for Colombia, Guyana. Hong Kong (China) and the Pinippines ate ror 1995; and for ladenesia ate for 1994. Al: other data are for 1998. The net secondary entollnent fior Brazil has been

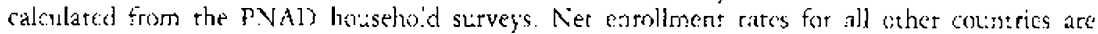
from LiNFSCO. Countries with net precicted net scendary earollment atios above 100 were

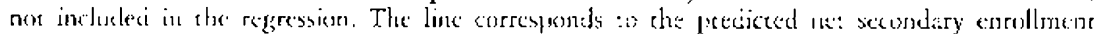
rase from it weightec regrossion on log per apira GloP and a constant, with the weights given

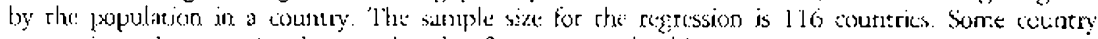
names zave becn onsted to make the figure rore legtbie.

SOURCE: as licranti e: al. 2003 )

By comparison to the secondary deficit prevailing in much of the tegion, the situation at the tertiary level is less clear cut. Some countries show higher levels of tertiary education than would be predicted by GDP, some lower. The average picture is one of a deficit. though substantially smaller than at secondary level 


\section{(10\%)}

Why should one be concemed about Latin America's deficit in secondary education? The most obvious concern - and one of grat cconomic importance - is that perhaps as much as three quarters of the region's potential labor force possesses at most only a fow years of basic primary education. As a result, many can be cxpected to have limited capacity and flexibility readily to accuire new skills: qualitics that employers seek in a workplars that necds constantly to change to stay competitive, and gualities which are generally recognized to be fostered by at least several years of secondary education. Beyond this, the relatively narrow field of secondary graduates relative to the size of the tertiary sector likely implies that many of these societies' most able children will not be among those progressing to higher education. More broadly, international experience indicates that successful expansions of educational systems, whether in the Liniced States between 1850 and 1950 , or in Europe and East Asia in more recent years, have been undertaken in a balanced and "borrom up" manner, rather than in the unbalanced manner that characterizes much of Latin America today.

Connections between Latin America's high levels of inequality overall and the unequal and imbalanced nature of educational development appear to tun in both directions. It is natural to suggest that families in the (relatively small) upper end of the income distribution are well placed to obtain strong allocations of resources for their children's education -- whether through their own privace resources or their infuence over public policies and patterns of government spending - while the larger proportion of the population settles for much less. As noted earlier, this tends to be crue a fintion for groups like the indigenous and Afro-descendants. In turn, unequal educational distribution clearly serves as an important channcl for perpetuating inceiuality across gencrations.

Thus far, discussion has focused essentially on quantitative indicators. Bcyond this, indications of the gualitative dimension of education give considerable cause for concern. On the relatively rare occasions that students from Latin Anerican countries have participated in international standardized tests of achievement, they have tended to score at or close to the bottom of the comparator group. Thus, ejghth-grade students from Colombia and Chile, taking part in, respectively, the 1995 and 1998 rounds of the Third International Math and Science Study (TIMSS), were among the weakest participants internationally, performing substantially worse than students from countries at comparable levels of development, and on a par with students from much poorer countrics. Tikcwisc, fifteen-ycar-olds from Brazil and Mexico were the two worst pertorming groups in the OtECD-sponsored Program for International Stutent Assessment (PISA).

It is not entirely obvious that the reaknesses identified in Latin American educational systenas can be attributed to inadequate levels of aggregatc expenditure. On the face of it, World Bank daca suggest that Latin American governments may on average spend a higher propertion of GDP on edication than East Asian countrics: 
an average $4.37 \%$ of GDP in 1995 for twenty-four Latin American and Caribban countries, compared to $2.60 \%$ for seven East Asian countries (de Ferranti et al. 2003,84 ), though it is not clear that these data are fully comparable in their coverage across different countries. Going boyond totals, there are indications that the composition of expenditures in Latin America is frequently skewed - in favor of the tertiary sector, for example, and/or against primary and secondary schools in rural areas and poorer regions or neightorhoods. Beyond this, though, a notable finding is the relatively weak relationship across different countries within Latin America between levels of expenditure and educational achievements (de Ferranti ct al. 2003,85$)$.

In this context, without downplaying the role which improved financial allocations (including more equitable distributions across schools) may be able to play in improving access to and availability of education (and, under certain circumstances, its quality too), analysts stress the need to look at other clements of educational systems as well. This includes the incencives and opportunities that apply to students, their families, and their communities; to teachers themselves and their associations and unions; to principals and officials; to potential or actual private or non-governmental providers of education; and to employers as interested "consumers" of the "output" of the educational system. Some of the most successful recent efforts to improve educational outcomes actively seek to change incentives and often to involve actors beyond direct educational providers.

Latin American countries are experimenting with a wide range of reform designs in the educational system. Reforms that seem to have helped increase the number of children attending school include the "conditional cash transfers" (discussed earlier) to poor families that keep their children in school (e.g., Brazil, Mexico), as well as "capitation" programs under which public spending "follows the student," thus providing incentives to school districts to boost school attendance (e.g., Brazil). The EDUCO program in El Salvador and comparable programs elsewhere, which increase the parcicipation of community and parent groups in the management of local primary schools, are credited with improving levels of registration, roducing student (and teacher) absences, and improving learning outcomes. More generally, though, substancial improvements in qualitative indicators have been more difficult to achieve than quintitative increases in attendance. Experiments are under way with variants of performance-based financing for schools and;or individual teachers in Chile and Mexico, and with school vouchers in Chile, though full consensus has yet to cmerge on the impact of these programs on educational outcomes or their potential replicability across different countries.

\section{Innovation}

As noted carlict, the quality of the educational system is one of the elements contributing to the productivity of Latin America's workforce, including the ability 
of workers to adapt to changes in technology. As such, education forms part of a larger set of concerns about the capacity of Latin American countries to manage innovation effectively. Aggregate measures of productivity growth are one warning sign that Latin American countries have had, on average, difficulties in taking full advantage of the economic potential of sew technologies. During the so-called "lost decade" of the 1980s, when much of Latin America was mircd in macroeconomic: stagnation, the GDP-wcighted growth of total factor productivity (TFP) in the region was, perhaps not surprisingly, negative (minus $0.93 \%$ per annum); but even in the 1990s, with the impact of reforms and economic recovery, the annual rate of improvement was a relatively modest $0.45 \%$. This compares to annual TFP growth for the "East Asian Tigers" of $2.18 \%$ in the 1980 s and $1.42 \%$ in the 1990 s, and for the set of "natural resource-abundant countries" of $0.76 \%$ and $0.78 \%$ respectively (de Fertauti et al. 2003, 25). Other indicators of innovation, such as levels of research spending per worker, number of patents filed, or degrece of computer penetration, tell a similar story.

Analysis of factors associated with stronger or weaker innovation indicates that the extent of competitive pressure experienced is positively correlated with the effort put into innovation. In this sense, the opening of Latin American markets to greater international competition via trade and FDI, together with specific measures of domestic market liberalization (e.g. in the area of elccommunications), can be seen as important positive steps, which may well have played a significant role in the productivity improvements seen in the 1990s. By thomselves, however, these reforms could not be expected to close the gaps in technological performance between Latin American countries and their comparators. As secn already, the educational systems in the region do not compare with those in potential competitors. More broadly, analysts find that in spite of success stories in some specific sectors and countrics, much of Latin Amcrica still has a way to go in developing effective "learning networks" that link universities, research institutions, and enterprises in a common endeavor to apply the latest thinking to the practical challenges of the workplace. Developing improved incentive patterns and links between these different playcts is thus seen as a priority for couneries in the region (this set of issues is explored in greater detail in de Ferranti et al. 2003).

\section{CLIMATE FOR BUSINESS}

\section{Regulatory Climate}

Clearly related to the challenges discussed above is the full range of factors that bear on the business environment for entrepreneurs, large and small, domestic and foreign, within the countrics of the region. Analyses poim to poorly-defined property rights, complex and inconsistently appliced regulations, and unpredictable judicial 
systems. In many cases, smaller enterprises may suffer worse; as noted earlier, many of these funcrion in the legally ambiguous environment of the informal sector.

As mentioned earlier, an influential study of the business climate for small operators in the informal sector was that undertaken by de Soto (1989) and his associates in Lima, Peru. In a much-quoted expcriment, the researchers undertiok to establish a stnall firm (specifically, a small, unincorporated, singk-proprietor garment factory) in full compliarnce with all applicable laws and regulations (and paying bribes only when failure to do so would unavoidably bring the process to a halt ${ }^{6}$ ). They found that the process absorbed 289 person-days of their time to comply with the eleven different permit requirements, a cash outlay of US\$194.40), and a total cost (allowing for the opportunity value of time) of around US\$1,231, or thirty-two times the monthly minimum wage.

De Soto's (1989) work in Peru has leelped inspire others to take up some of rhe same issues, not only clsewhere in Latin America but on a global basis. Inter alia, the World Bank Group has to date undertaken Investment Climatc Surveys (ICS) in fifty-six countries, with coverage of a toral of 26,000 firms of all sizes. In parallcl, the Bank's recently-launched annual "Doing Business" serics (commencing with "Doing Business in 2004") assesses the complexities and costs of undertaking various key business functions (e.g., starting a business, hiring and firing workers, obtaining a loan, enforcing a contract, etc.) across more than 130 countries, based on the estimates of credible experts in local business and legal conditions.?

These two complementary sources provide rich romparative country-level data on business climate on a glohal basis. They have helped to demonstrate that matly of the issues raised by de Soco's (1989) work in Pcru resonate in many countries across the region and the world. At the broadest level, these sources provide empirical justification for such otherwise apparentiy sweeping generalizations as 1) "poor countries regulate business the most"; 2) "heavier regulation is associated with informality and corruption"; 3) "more regulation is associated with higher costs and delays"; and 4) "more rigid employment regulation is associated with higher female unemployment." But the benchmarking process is also helping to turn up more practical ways in which countries may, with the necessary will, be able to larn positive lessons from one another's experiences: for example, "credit bureaus are associated with more credit" and "[requircments for the involvement of] notaries are bottlenecks to business start-up."

Both the ICS exercise and the "Doing Business" analysis identify many Latin American countries as among those with serious issues of inappropriate regulatory climates (though it should be emphasized that such issues are far from being unique: to I.atin America, and indecd can be found in all regions). According to the lCS, for example, "Brazil has the highest percentage of firms that say processes for obtaining business licenses and permits present serious obstactes to doing business." Meanwhile, "Doing Business in 2004" records that "in Bolivia, one of the most heavily regulated economies in the world, an cstimated $82 \%$ of business activity 
takes place in the informal sector".

As noted earlier, these studies can also offer positive lessons and reinforcement to countries that are sufficiently motivated to take on the vested interests whose activities lie at the heart of many of the problems identified. Honduras and Jamaica, for example, are reported als having significantly simplified business registration procedures; Chile, Colombia and Uruguay, as having eased excessive regulation of the labor market. Mexico is identified as a leader in the simplification of debr collection procedures; Colombia is singled out in the 2005 edition of "Doing Business" as one of the countries that had made the grcatest improvement in business climate over the previous year. This being saic, it should be clear that the long-term challenge of improving the regulatory climate is not, in general, as simple as changing regulations with the stroke of a pern. The orientation and culture of the public sector will ued to be redirected in fundanental ways if the kind of self-serving behavior that underlies most inappropriate regulatory conduct is not to reemerge after each eftort at regulatory simplification and reform.

\section{Infrastructure}

Costs of doing business also reflect the state of plysical infrastructure within the region." Overall, coverage for nost infrastructure services has improved significantly across the region over the past two decades. Improvements bave been especially notable in the areas of elephone service (fixed linc; hue also very srrikingly cellilat), and also electricity, and water and sanitation; however, there has generally becn litcle improvement in coverage in transportation (roads, ports, and railways). Comparisons with other middle income countries also produce mixed results. Latin Ametica does relatively well compared to an arcrage of middle income countries (and to China) in the coverage of water and sanitation, while its superior pertormance in expanding access to cellular phones nore-ert-less compensates for less extensive fixed line coverage. By contrast, coverage of dectric power remains well behind the comparators, and road coverage also appears inferior though cross-country comparisons in this area ase complicared by differences in topography and population density).

This rather mixed picture notwithstanding, there are indications that, in overall terms, deficiencics in the quantity and cluality of infrastructure represent important constrants to productivity in the region. In responses to Workd Bank Investment Climate Surveys, an average of $55 \%$ of firms in Jatin America cites infrastructure deficiencies (power, telecommunications, andior transportation) as a major or severe obstacle to the operation and growth of their business. This proportion is comparable to that seen in the Middle Easr and North Africa, and represents the highest level of concern across regions; on average, less than $20 \%$ of respondents in East Asia express comparable concern over infrastructure. Microeconomic studies find that logistics costs for Latin Ancrican tirms arc well above OLCD avcrages. Some 
recent macroeconomic studies suggese that feasible improvements to infrastructure could go a substantial way to raise typical growth races in the region, as well as to improve living standards directly.

In revicwing some of the key factors involved in recent Latin American infrastructure performance, we find a mixture of forces that have pushed in conflicting directions. 'I'he fiscal adjustment faced by Latin American countries, as a result of the macroeconomic crises of the 1980s and subsequent ytars, fell especially heavily upon public investments in general, and public investment in infrastructure in particular (World Bank and Inter-American Development Bank 2005, 18). As a share of GDP, for example, public infrastructure investment fell between 1980-84 and $1995-98$ by 1.98 percentage points in Mexico, and by 3.08 percentage points in Brazil. However, during most of the 1990s, Latin American countries managed to compensate at least partially for these drops in public investments by becoming leaders on a worldwidc basis in the attraction of private infrastructure investment. Altogether, some $48 \%$ of the total US, $\$ 86$ billion of private participation in developing colinery infrastructure during 1990-2003 went to Tatin America.

In evaluating this increased private provision of infrastructure in the region, the analyst confronts a paradox. Most analytical studies tend to point to generally quite positive outcomes in the shape of broadened coverage of services (including beter access by the poor), improved operational efficiency and service quality, and in some cascs lower costs to consumers (though by no means always, at least iu. part hecause earlier arrangenants ofern involved heavy implicit subsidies). Yet in parallel, percettion of private provisions on the part of public opinion have in many countries moved sharply in a negative direcrion over recent years, apparently reflecting concerns over such issues as the transparincy (or lack thereof) of bidding arrangements, frequent contract renegotiations, selective price rises, and immediate direct job losses in some utilities.

If public provision has suffered from poor "public relations" within many of the host countries, simulaneously "ennerging markets" have lost favor among international investors, in part due to renewed macroeconomic instability during the late 1990 s and early 2000s, as well as increased awareness of regulatory complexities. Total investment in infrastructure projects with private participation dropped in Latin America from a peak of LS\$0.8 billion in 1998 to US\$15.7 billion in 2003. As data for 2004 start to become available, they show some signs of at least a partial upturn in private investment in intrastructure in the region. ${ }^{10}$ The point remains that Latin Ancrican countries face significant challenges in any cffort to resume: adk lossing their infrastructure gaps by whatever combination of public, private, and mixed provision - both substantive challenges in the design of incontives and regulatory systems; fiscal and cust-recovery challenges, especially in the case of primarily public provision; and also to some degree political and communications challenges as regards the current widespread adverse public perceptions of private provision within the region. 


\section{LATIN AMERICA AND THE WORLD}

Having opened their economies decisively to international trade, Latin Americans face new concerns about how they will thrive in a globalizing world. Where will their future comparative advantage lie? Should they see China's emergence as a cause for concern. or as a source of enormous opportunicies? Il

One of the features of the import-substituting itudustrialization (ISI) era in Latit America was a whole range of policy measlires that discriminated against sectors closely rclated to the exploitation of natural resousces (agriculture, mining, etc.). These incentives, and the policy of promoting manufacturing which they supported, depended for much of their intellectual support on the work of analysts, like the late Raul Prebisch, who were pessinistic both about long-term price prospects for commodities and abour the potential for significant productivity improvement in primasy sectots. For many years, analysts have been awarc of some of the distortions created by high levels of protection for favored manufacturing sectors, and - as noted earlicr - policynakers have gone a considerable way toward cutting back such protection. Reyond this, recent analytic work has also exposed earlier assumptions ahout natural-resource based developmene to more critical scrutiny, demonstrating both that Prebisch's analysis of long-term price trends was flawed, and also that commodiry-based sectors can, with appropriate efforts at applied research, prove every bit as technologically dynamic as manufacturing. 1 ?

Indecd, natural resources, whether primarily agricultural or mincral, are likely to continue to provide a major source of comparative advantage for many of the region's economies. Southern cone economies such as Brazil, Argentina and Unuguay, for example, would be among the main winners from any dramaric liberalization in world agricultural trade that might emerge from the Doha Round. ${ }^{3}$ Minerals - metals and/or hydrocarbons - are key resources for many of the Andean economies, among others. Given the Chinese economy's highly constrained domestic availability of cultivable land and of most mincral resources, Clina's recent dramatic growth has been highly intensive in inpors of mineral and agriculnural raw materials. This has been very good news for Iatin American cconomies with endowments in these areas, and future prospects appear encouraging for this type of trade.

The recent analycical work cited above points to the importance of developing improved "learning networks" for the region's kcy natural resource-based sectors. It is ifonic, for example, that a mining corporation from Australia, a country that entered the mining industry far later than Chile, was responsible for discovering the largest copper deposit in Chile. Yet the irony highlights the more effective learning networks that Australia has developed within the mining sector, networks that Larin Anetican countrics need to emulate, not just in mining, but across the key sectors of their economies.

But countries in the region do not all share the same resource endownents or opportunities. Other cxport models less closely based on natural resources are 
also being explored by various countries in the region. Lnder NAFTA, Mexico has substantially expanded its exports of manufactured and assembled items to the US, and othcr countries in the Caribbean basin and Central America hope to take similar advartage of their proximity to the LS market. More selectively, both Costa Rica and Chilc have sought to make improved education and tcchnology work to their benefit, Costa Rica in its atraction of Intel and related technology investments, Chilc inter alia by adding value and moving up-market with many of its natural tesource based exports.

Overall, Iatin Americans increasingly recogrnize that they will not be able to compete in ficlds like manufacturing and assembly with countries like China purely on the basis of labor costs. This in turn places an added premium on efforts to raise productivity through improved education, a better business climate, and enhanced inffastructure - all issues this paper has sought to address - and to develop niche markets that take advantage of latin American countries' locational and other adyantiages.

\section{CIOSING OBSERVATIONS}

Without purporting to achieve comprehensive coverage of all the policy issues that Latin Ametican countries confront, the above discussion has attempted to highlight if few central aspects of the datlenges facing the region. I low decision-makers address these challenges will go a loner way in determining how their countrics fare. Fach of the challenges is, in part at least, "political" in nature, with potentially important implications for huw different groups interact in the furure.

Some of thesc challenges pose special quandaries for what some may call the elites of the countries, but which are pcrhaps better described as the "more advantiged groups." By this, we rofer to all those who reap advanages, compared to the broad mass of their fellow citizens, from the current structure of society and the present desiga of institutions. This indudes the more traditional concept of the elite - the politically influential large businessman or farner, for cxample. But the circle of the "advantayed" is wider than this. Compared to the broad mass of Brazilians, for example, the "advantaged" may include the Brazilian civil servant, even if in a relatively lowly position, who enjuys effective life tenure and a generous state-provided pension. Indeed, in many countries in the region, almost anyone holding a "formal" sector job, with its access to socially-provided bencfits, may be: considered advantaged by local standiards.

If Larin American countries ate to break out of the "low-level equilibria" portrayed in this paper - compatatively slow growth high poverty, inecutrality, and informality; weak educational levels; slow technological progress; unsure futture comparative advantage - with potential long-run gains to their socicties as a whole, they will need inter alia to find more effective ways to lower sume of the barriers which 
today divide their populations into more and less advantaged groups - indigenous (or black) and "white," highly educated and poorly educated, formal and informal. This will call for finding ways to overcome and disarm the fears and putential resistance of some who currently benefit from being on the more advantaged sicle of those divisions. That, it turn, will provide a fundamental test of the political capabilities within cach of these socictics.

\section{REFERENCES}

Burki, Shahid Javed, and er al. 1998. Beyond the Washington Consensts: Institutions Matser. Washington D.C.: The World Bark.

- 1999. Beytind the Center: Decentralizing the Siats. Washington D.C.: The World Bank.

Chen, Shaohua and Martin Ravallion. 200\%. Hou Have the World's Poorest Forred ince the Early 1980s: Washington D.C.: The World l3ank.

De Ferranti, loavid, and et al. 2002. From Natural Ressimw to the Knouledge Economy: Trade and Jab Quilit, Washingeon D.C.: The World Bank. . 2003. Clasing the Gap in Eduction and Tobnolog\}, Washington I).C.: Thic World Bank.

200.1. Inequality in Latin Amirial Breaking uith History? Washington D.C.: The World Bank.

De Soto, Hernando. 1989. The (ther Path: the Invisible Rennlution in the thint world. New York: Harper Collins.

Fay, Marianne and Mary Morrison. 2005. Imjastructure in Latin America: Recent Dowelnpments and Ka Cbollenges. Washington D.C.: The World Bank.

I Lall, Gillette: and Larry A. Patrinus, eds. Furthcoming. Indigenous penple, fonerty:

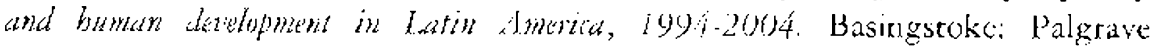
Macmillare.

Inter-American Development Bank (IADB). Forthoming. The Emerence of Cbrink: Oppontumities and Cirallonger for latin Ameria and the Caribean. Washington D.C. Inter-American Dialogue (1AD). 2003. Afro-Desienduits in Latin America: Hon Man)? Washington D.C.

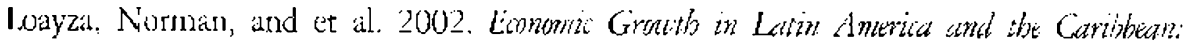
Siglized ladis, Explanations, and Forecasts. Washington D.C.: The Workd Bank. 2003. Fonmmic Grouth in Iatin Ameriat and the Caribbean. Conference

Presentation.

OECD. 2001. The Word Fonnony: A Millonnid Peripertive. Paris.

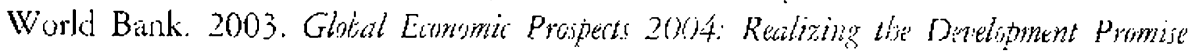
of the Dobo Agrada. Washington D.C.: The World Bank 2004. Daing buines in 2014. Washington D.C.: The World Bank. 2005. Privati Water Projets. Public Policy for the Private Sector Note 


\section{No. 297. Washington D.C.: The World Bank.} No date. Investment Climate Sumey. Accessible via World Bank website.

\section{ENDNOTES}

${ }^{1}$ Execpt whese otherwisc specified. references in chis secrion are drawn from de Fersanci et al. (20040).

"Note, thuugh, that terms like "jndigenous" and "Afro-descendant" do not necessarily lend themselves

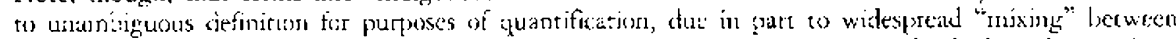
popwiacions of different origias, but also to differences in perceptisns imong individuals ard wer :ime.

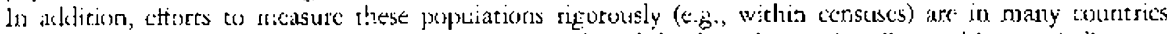
of very recent origin. The indigenous population is ofren detined as those primarily speaning an indigenous rather than a European anguage. Alj alternative approach, which can yield significantly dificrcul tescles: farers "sclf ideutification" by tespoudents. About 10\% of the region's population scpotedly identify chenselves is indigenuus, rowygh the ratio is as high as 71 percent in Bolivia and 66 perceat in

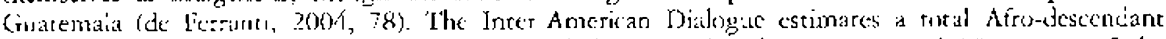
popilation of 120 million for Latin America including the Cariobeen, or asound 30 percene of the cotal population (1AD, 2003). It allus: be stessed that these two estimates are by no arcans mutually

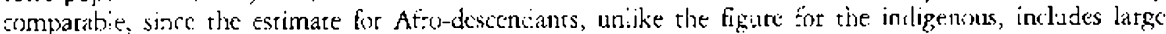
aumbers who regard :hernsclves (and are viewed by others) as being of "mixcd" ancestry.

"A numler tot auntries. including horh Mexice ane Brazil, have atopted programs that provicie modest cash transfers to puor fisroilies providel recipients meet enditions such as kecping children in sct.ool

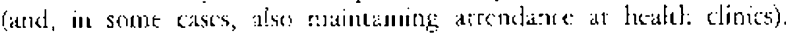

Except whete otherwise specified, refirences in this secton arc drawn from De Ferranti ct al. (2003). The comparatwe work that is discussed here compased latin Anerican conncrics primatiy to swo groups of con:parators: 1) :he "Fast Asian cigers" comprisisg Hong Kong (Chinat Korea, Malaysia. anc: Singapore: and 2) a group of "nacurai, resiarse-abundant councries" comprisng Canada, Australia, New 7ealand. Finland. Norwisy, and Sweden.

"Some adcitional insigh: into comparative stand-äds at the primary level unthon Latin America, including

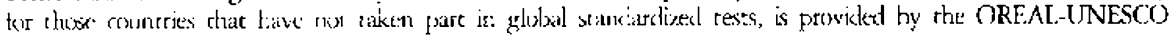
exams. These sest sird anc fousth greaders on language and math skills in 12 l.atis American countrics

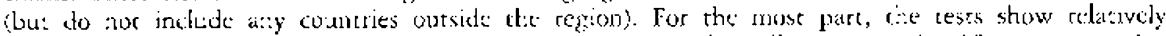

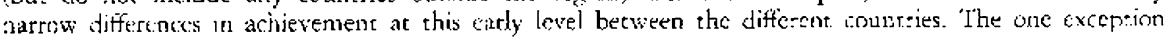
is Cuba: wheth scorcs signiticastly better than che otleer participaring countries.

6: The rescarchers were asked for bribes on en occasions. On eight, they managed-wich some diffouty-to circumvert the neted to pay: on two, rhey could sec no altessative to paying the bribe.

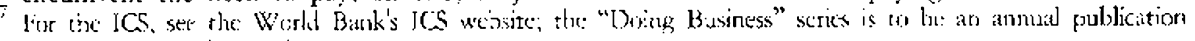
isee Worid Bank 20(ib).

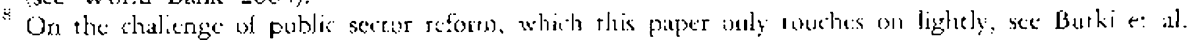
(19)8).

"Excert where otherwisc spectice, reterences in this section are ciawn fromi lay and Morrison (2005).

"See World Biak 2005 ; which repurts a modest revival in 2004 with the water and sewerage sector, albeit concent:ated in a hasdtui of countries. Comparabls data for other secromb were not yel available when the present arrisk: was ti:balizeal fore publication.

1: On China ard Latin America, sec especially Inter-Arrctican Develciment Bank forcheoming).

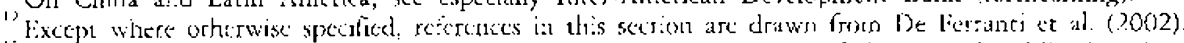

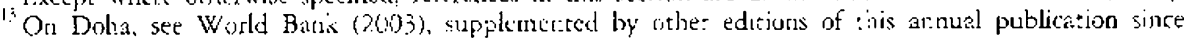
$20(12$. 